Article Type: Research Paper

\title{
The Effect of Relationship Marketing and Service Quality Towards Customer Loyalty of PT Bank Perkreditan Rakyat Sumatera Selatan
}

\author{
Marzuki ${ }^{1 *}$, Zakaria Wahab ${ }^{1}$, Marlina Widiyanti ${ }^{1}$, and Muchsin Saggaff \\ Sihab $^{1}$
}

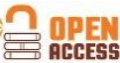

\section{AFFILIATION:}

${ }^{1}$ Department of Magister

Management, Faculty of

Economics, University of Sriwijaya, Indralaya, Indonesia.

\section{*CORRESPONDENCE:}

Mzuki1907@gmail.com

THIS ARTICLE IS AVALILABLE IN:

http://journal.umy.ac.id/index.php/mb

DOI: 10.18196/mb.11296

\section{CITATION:}

Marzuki, Wahab, Z., Widiyanti, M., Sihab, M.S. (2020). The Effect of Relationship Marketing and Service Quality Towards Customer Loyalty of PT Bank Perkreditan Rakyat Sumatera Selatan. Jurnal Manajemen Bisnis, 11(2), 177-187.

\section{ARTICLE HISTORY}

\section{Received:}

06 August 2020

\section{Reviewed:}

12 August 2020

26 August 2020

Revised:

17 August 2020

18 August 2020

Accepted:

28 August 2020

\begin{abstract}
This study aims to determine whether relationship marketing and service quality affect customer loyalty at Bank BPR Sumsel. This study used a causal research method, an inference research type to realize cause-and-effect, determine the influence of the variables that are the cause (independent variables), and the effect (dependent variable) of a phenomenon. The data used in this study were primary data by distributing questionnaires to deposit customers at the Head Office of the Bank BPR Sumsel. The number of samples used as respondents was 100 . The data analysis technique used in this study was multiple linear regression analysis, which was previously tested for validity and reliability. The results obtained are relationship marketing and service quality have a positive and significant effect on customer loyalty at the Bank BPR Sumsel. From the test results, the $R^{2}$ (R Square) value of 0.691 or (69.1\%) indicated that the percentage contribution of the independent variables' (RM and SQ) influence on the dependent variable (customer loyalty) was $69.1 \%$. Alternatively, the independent variables used in the model (RM and SQ) could explain $69.1 \%$ of the dependent variable (customer loyalty). Meanwhile, the remaining $30.9 \%$ was influenced or explained by other variables not included in this research model such as pricing, brand image, and customer values.

Keywords: Relationship Marketing; Service Quality; Customer Loyalty; PT Bank Perkreditan Rakyat Sumatera Selatan.
\end{abstract}

\section{Introduction}

In the last few decades, Indonesia has become one of the developing countries whose development is swift. The Indonesia's economic growth momentum was maintained, as reflected in Indonesia's relatively stable economic growth in the fourth quarter of 2018. The GDP growth realization in the fourth quarter of 2018 was recorded at $5.18 \%$ (YoY), an increase compared to the previous quarter's achievement, which was $5.17 \%$ (YoY). With this development, economic growth in 2018 was recorded to have increased from $5.07 \%$ in the previous year to $5.17 \%$ and was the highest achievement in the last five years (Bank Indonesia Press Release). 
The Effect of Relationship Marketing and Service Quality on Customer Loyalty ...

One of the keys to successful development is strong support from the banking sector. The banking sector has a function and role as an intermediary institution, as stipulated in Law of the Republic of Indonesia Number 10 of 1998 concerning Banking. It collects funds from the public in the form of deposits and channels them back to society in the form of credit savings or other forms to improve people's lives.

Activities to collect funds from the broader community in banking terms are known as funding activities. The bank collects funds from the public with various strategies so that people are willing to invest their funds in the form of deposits such as current accounts, savings, or time deposits. Furthermore, the funds that have been collected from these third parties are channeled back to the community in the form of loans or credit (lending). Apart from commercial banks, there is one type of bank intended to extend credit to the MSME sector, namely BPR. According to OJK Regulation No. 4/POJK.03/2015 concerning Implementation of Governance for BPRs, they carry out conventional business activities which in their activities do not provide services in payment traffic (checking account/bank clearance, and others).

One of the BPRs in the South Sumatra province is PT Bank Perkreditan Rakyat Sumatera Selatan, a Regional Owned Enterprise (BUMD) whose shares are owned by the South Sumatra Provincial Government (hereinafter referred to as Bank BPR Sumsel). Bank BPR Sumsel was founded on January 21, 2008. It is headquartered in Palembang and has two branches: Lahat Branch and Sekayu Branch.

To maintain customer loyalty, Bank BPR Sumsel implements a prime service strategy, including providing competence in the service department (teller and customer service), a comfortable banking hall, and speed of service processes. Besides, a Cash Pick Up service program is also provided for customers who do not have time to go to the bank. BPR Bank management also has a strong commitment to building good long-term relationships with customers by creating customer loyalty programs, such as giving birthday cakes to birthday depositors or giving gifts on religious holidays.

Furthermore, literacy about customer loyalty has been widely published in the literature, including about gaining competitive advantage through customer satisfaction and customer loyalty (Stauss, 2013); how to build customer satisfaction through reward, challenge, and contest programs (Zichermann \& Linder, 2010); increasing revenue, profit, and customer loyalty through 3600 sales cycles (Nick \& Koenig 2004).

In the banking world, several studies have been conducted on the effect of relationship marketing on customer loyalty, such as Ratnasari and Gumanti (2019), Basyir and Ramiasih (2017), Synathra and Sunarti (2018), Hasan (2019), Solangi, Talpur, Shaikh, Mushatque, and Channa (2019), and Boateng (2019), who concluded that relationship marketing had a positive and significant effect on customer loyalty. The results of this study are different from research conducted by Khotimah, Suharyono, and Hidayat (2016), who argued that relationship marketing had no significant and negative effect on customer loyalty, but had a significant and positive effect through customers satisfaction. 
Besides, research on the effect of service quality on customer loyalty was done by Boonlertvanich (2019), Saputra, Zulkarnain, and Samsir (2018), Basalamah, Moeljadi, Sunaryo, and Sudjatno (2018), and Synathra and Sunarti. (2018), who concluded that service quality had a positive and significant effect on customer loyalty. In contrast to the research results of Salilo (2019), it concluded that product quality (service) had no significant effect on customer loyalty.

Based on the literature and journal references, research related to marketing and service quality is essential to enrich knowledge regarding marketing strategies and customer service, especially in BPRs. Therefore, the authors are interested in conducting research with the title "The Effect of Relationship Marketing and Service Quality on Customer Loyalty of PT Bank Perkreditan Rakyat Sumatera Selatan".

\section{Literature Review and Hypotheses Development}

\section{Relationship Marketing}

Kotler and Keller (2012) explain that relationship marketing aims to build mutually satisfying long-term relationships with key parties to get and maintain their business. Ndubisi (2007) states that four key values support marketing relationships: trust, commitment, communication, and complaint handling. The four basics of relationship marketing are directly related to customer loyalty.

\section{Service Quality}

Armstrong and Kotler (2015) define services as activities or benefits offered for sale, which are entirely intangible and do not result in any ownership. Service quality is more difficult to define than product quality. Customer retention is perhaps the best measure of quality, which is the company's serviceability to keep its customers consistent with the value the company provides them. In contrast to product manufacturers who can adjust their machines and inputs until everything is perfect, the service quality will always vary, depending on the interaction between employees and customers.

Kotler and Keller (2012) explain that service quality is tested in each service implementation. In general, customers compare the perceived service with the expected service. If the perceived service is below the expected service, then the customer is disappointed. Customers will be very satisfied if they get an experience that exceeds their expectations.

According to Parasuraman, Zeithaml, and Berry (1988), the customers' requirement to understand what they can expect to get and what they actually get is usually applied to determine the service quality from customers. Furthermore, the research of Zeithaml, Bitner, and Gremler (2013) showed that customers did not perceive quality initially, but assess quality based on various factors that are relevant to the context. The service quality dimensions have been identified by pioneering research, Parasuraman, Zeithaml 
The Effect of Relationship Marketing and Service Quality on Customer Loyalty ...

and Berry (1988), who have identified five main service dimensions, known as the SERVQUAL model managed in various service contexts: reliability, responsiveness, assurance, empathy, and physical evidence (tangibles).

Tjiptono (2019) argues that services are intangible and are a process that customers carry out subjectively. In this process, interactions occur between customers and service providers, which will significantly affect the customer's perceived service. Thus, it includes the service quality principle, efforts to fulfill customer needs and desires, and the delivery accuracy to meet customer expectations.

\section{Customer Loyalty}

According to Griffin and Herres (2002), customer loyalty is more related to behavior concerning attitudes. Loyal customers have specific prejudices about what to buy and from whom. Loyalty denotes the condition of specific time duration and requires the purchase action to occur no less than two times.

Tjiptono (2010) states that repurchasing behavior with a strong brand sensitivity situation can be categorized as loyalty, in a condition that consumers tend to repurchase the same brand and consider the brand choice to be very important to themselves. Furthermore, Tjiptono (2019) argues that customer satisfaction is never enough. Customers can switch suppliers if they find better suppliers or service providers. Therefore, customer satisfaction must be accompanied by customer loyalty. The loyalty concept itself is complex and dynamic. Repurchases do not necessarily reflect loyalty. At least three conditions cause it: expensive to change, high risk of change, namely no guarantee of faulty performance of new service provider, and self-protection and change. In some cases, customers prefer to establish relationships with many service providers to get various products and services, low prices, etc.

Bank BPR Sumatera Selatan had several marketing programs aimed at maintaining customer loyalty. For example, when a funding customer had a birthday, the customer service would call the customer, even came directly with a birthday gift package. Also, on religious holidays, the customer would be given a gift package. Customers were highly appreciated, so they tended to be loyal to BPRs. Therefore, relationship marketing is also an important factor affecting customer loyalty. According to Ratnasari and Gumanti (2019), relationship marketing had a positive and significant effect on customer loyalty. In several other studies, such as Basyir and Ramiasih (2017), Synathra and Sunarti (2018), Hasan (2019), Solangi et al. (2019), and Boateng (2019), it was found that relationship marketing had a positive and significant influence on customer loyalty.

As a company engaged in the financial services industry (IJK), service quality is Bank BPR Sumsel's particular concern to maintain customer loyalty. Periodically, all Bank BPR Sumsel employees received training or refresher training with service excellence material to establish a service culture at Bank BPR Sumsel. According to the research results of Boonlertvanich (2019), Saputra, Zulkarnain, and Samsir (2018), Basalamah, Moeljadi, Sunaryo, and Sudjatno (2018), the relationship between service quality and 
customer loyalty showed that service quality had a positive and significant effect on customer loyalty.

From several theories and several previous studies that have been described, this research can be explained in a conceptual framework, as shown in Figure 1:

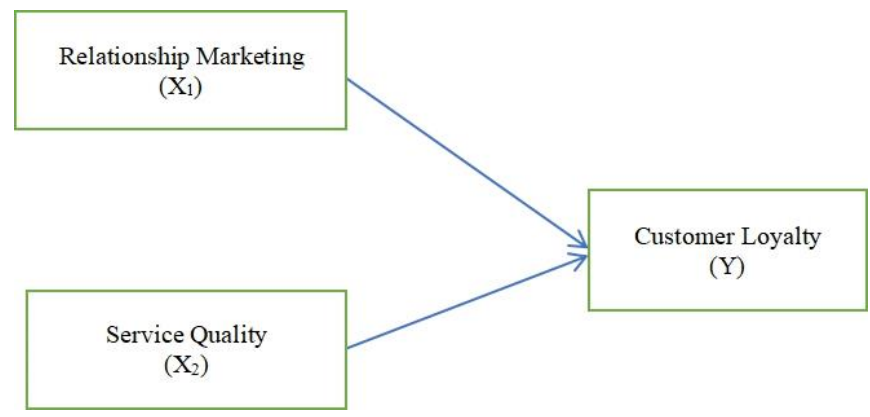

Figure 1. The conceptual research framework

Based on the background, the problem is supported by theoretical research and has a conceptual framework. Therefore, the authors proposed the following hypothesis:

$\boldsymbol{H}_{1}$ : Relationship Marketing affects customer loyalty of PT Bank Perkreditan Rakyat Sumatera Selatan.

$\boldsymbol{H}_{2}$ : Service quality affects customer loyalty of PT Bank Perkreditan Rakyat Sumatera Selatan.

\section{Research Method}

This study used a causal research method, an inference research type to realize causeand-effect, determine the influence of the variables that are the cause (independent variables) and the effect (dependent variable) of a phenomenon. This research scope was to analyze the effect of Relationship Marketing and Service Quality on Customer Loyalty at PT Bank Perkreditan Rakyat Sumatera Selatan.

\section{Population and Respondent}

In this study, the population was funding customers - deposits (or depositors) at the Operational Head Office (KPO) of Bank BPR Sumsel located in Palembang city. They were consumers who felt the impact of the marketing strategy and service quality of the Bank BPR Sumsel directly. It consisted of 134 individual savings customers. The consideration basis for population selection was the number of Bank BPR Sumsel customers at the Operational Head Office (Palembang), which was as much as $90 \%$ of the total depositors of Bank BPR Sumsel. It was considered adequate to be used as a research sample. To 
obtain a representative and proportional sample, this study's sampling technique was based on the Yamane approach statistical formula and the table for determining the number of samples from a particular population developed by Isaac and Michael. From these two approaches, a sample of 100 respondents was taken from deposit customers at the operational head office (KPO) of Bank BPR Sumsel.

\section{The Data Analysis}

Data analysis is a data processing activity collected to answer the problem formulation and test the proposed hypothesis. This study's data analysis technique was multiple regression analysis to see the effect of relationship marketing variables and service quality variables on customer loyalty of PT Bank Perkreditan Rakyat Sumatera Selatan. Based on the variables to be studied, the formula can be written as follows (Sugiyono, 2017):

$$
Y=\alpha+\beta 1 . X 1+\beta 2 . X 2+e
$$

Information:

$\mathrm{Y}=$ Customer Loyalty

$\mathrm{X}_{1}=$ Relationship Marketing

$\mathrm{X}_{2}=$ Service Quality

$\alpha=$ Constant

B 1.ß 2 = regression coefficient

$\mathrm{e}=$ factor failure

\section{Operational Definition and Variable Measurement}

The operational definition defines a concept or variable to measure it by looking at the dimensions (indicators) of a concept or variable. The Independent variable is a variable that affects and causes or changes the dependent variable. The dependent variable is the variable obtained because of the independent variables. To understand each independent and the dependent variables in this study, it can be described as follows:

a) Relationship marketing aims to build mutually satisfying long-term relationships with key parties to get and retain their business. Four key values support relationship marketing: trust, commitment, communication, and complaint handling. The four basics of relationship marketing are directly related to customer loyalty.

b) Service is any action or performance that one party can offer to another, which is essentially intangible and does not result in any ownership. Trial service quality is at each service implementation. There are five main service quality dimensions, known as the SERVQUAL model, which apply in various service contexts: Reliability, Responsiveness, Assurance, Empathy, and Tangibles.

c) Customer loyalty is a customer commitment to a brand, store, or supplier based on a very positive attitude and assessment of consistent repeat purchases. Three 
indicators reflect customer loyalty variables: repeat purchases, retention, and referrals.

In this study, the data method used a questionnaire. The measurement scale employed to express the respondents' responses to each question given was the Likert scale, which ranged from score 1 (Strongly Disagree) to score 5 (Strongly Agree).

\section{Result and Discussion}

Table 1 Determination Coefficient $\left(R^{2}\right)$

\begin{tabular}{cc}
\hline \multicolumn{1}{c}{ Model } & R Square \\
\hline $\mathbf{1}$ & 0.691 \\
\hline
\end{tabular}

From the test results, the $R^{2}$ ( $R$ Square) value of 0.691 or $(69.1 \%)$ indicated that the percentage contribution of the independent variables' influence (RM and SQ) on the dependent variable (customer loyalty) was 69.1\%. Alternatively, the independent variables used in the model (RM and SQ) could explain $69.1 \%$ of the dependent variable (customer loyalty). Meanwhile, the remaining $30.9 \%$ was influenced or explained by other variables not included in this research model.

Table 2 Linear Regression Analysis 1

\begin{tabular}{llcc}
\hline Model & & Unstandardized Coefficients & \\
& & B & Std. Error \\
\hline $\mathbf{1}$ & (Constant) & 0.851 & 1.080 \\
& Relationship & 0.090 & 0.040 \\
Marketing & & \\
& Service Quality & 0.134 & 0.024 \\
& a. Dependent Variable: Customer Loyalty (Y) & \\
\hline
\end{tabular}

Linear Regression Formula:

$$
\begin{array}{ll}
\mathrm{Y} & =\alpha+\beta_{1} \mathrm{X}_{1}+\beta_{2} \mathrm{X}_{2}+\mathrm{e} \\
\text { Customer Loyalty } & =0,851+0,090 \mathrm{RM}+0,134 \mathrm{SQ}+e
\end{array}
$$

The regression formula can be explained as follows:

- The constant was 0.851 . It signified that if the RM $\left(X_{1}\right)$ and SQ $\left(X_{2}\right)$ value were 0 , then customer loyalty $\left(\mathrm{Y}^{\prime}\right)$ was 0.851 .

- The regression coefficient of variable RM (X1) was 0.090 . It denoted if other independent variables had a fixed value and RM had an increase of $1 \%$, then the customer loyalty value ( $Y^{\prime}$ ) would increase by 0.090 . The coefficient was positive, meaning that there was a positive relationship between Relationship Marketing and customer loyalty. The higher the Relationship Marketing value, the higher the customer loyalty level.

- The regression coefficient of variable SQ $\left(\mathrm{X}_{2}\right)$ was 0.134 . It indicated that if other independent variables were fixed value and service quality increased by $1 \%$, customer loyalty $\left(Y^{\prime}\right)$ would increase by 0.134 . The coefficient was positive, meaning that there 
The Effect of Relationship Marketing and Service Quality on Customer Loyalty ...

was a positive relationship between service quality and customer loyalty. The higher the service quality, the more customer loyalty increases.

Table 3 T-Test (Significance Test of Parameters Individual)

\begin{tabular}{cccc}
\hline & Model & T & Sig. \\
\hline \multirow{2}{*}{1} & (Constant) & 0.788 & 0.433 \\
& Relationship Marketing & 2.268 & 0.026 \\
& Service Quality & 5.494 & 0.000 \\
\hline
\end{tabular}

1. Relationship Marketing (X1) produced a significant value at $\alpha=0.05$ because the tcount $>t_{\text {-table }}(2.268>1.985)$ or the value (Sig.) $0.026<\alpha=0.05$. Therefore, the first hypothesis, stating that the relationship marketing variable $\left(X_{1}\right)$ affects customer loyalty $(\mathrm{Y})$, was proven and accepted.

2. Service Quality $\left(X_{2}\right)$ scores Sig. $0.000<0.05$, or the value of $t$-count $>t$-table $(5,494>$ $1,967)$. Thus, the second hypothesis, assuming that there is an effect of Service Quality $\left(\mathrm{X}_{2}\right)$ on Customer Loyalty $(\mathrm{Y})$, was proven and accepted.

\section{Conclusion}

The Relationship Marketing variable had a positive and significant effect on Customer Loyalty at PT Bank Perkreditan Rakyat South Sumatra. It could be seen from the respondents' responses to several statements in the questionnaires distributed in this study. The questionnaire results of the relationship marketing variable with a score above the average research score were the statement 1) Bank BPR Sumsel paid attention to customer conditions in transactions, 2) Bank BPR Sumsel employees showed respect for customers, and 3) BPR Sumsel employees always provided the right solution to a problem before it became a serious problem. The high scores on these three statements contributed significantly to increasing the Marketing Relation variable values so that it had a positive and significant effect on the Customer Loyalty variable. It is in line with the theory developed by Ballantyne, Christopher, and Payne (2003) that relationship marketing focuses on maintaining good relationships with customers in the long term and emphasizing product benefits and high customer service.

In this study, the respondents' characteristics based on influential information sources were $40 \%$ of family and friends. It indicated that the communication dimension influenced increasing the relationship marketing value so that it had a positive and significant effect on the customer loyalty variable. From research at Bank BPR Sumsel, the average score was "Very Good" from three question items regarding the handling of customer complaints. It reflected that BPR Bank officers have been handling customer complaints very well. It, of course, would have an impact on increasing customer loyalty. This study contrasts with the research's results by Tjiptono and Dewi (2013), which concluded that banking was the 4th sector with the top rank of the ten service industries that received the most complaints from its customers. 
The Effect of Relationship Marketing and Service Quality on Customer Loyalty ...

Based on the results of the significance test, it also showed that service quality had a positive and significant effect on customer loyalty at PT Bank Perkreditan Rakyat Sumatera Selatan. From the frequency test results of service quality variables in this study, it showed that of the five service quality dimensions identified by Parasuraman, Zeithaml, and Berry (1988), the lowest score was in the tangible dimension, while for four other dimensions (reliability, empathy, assurance, and responsiveness), the questionnaire score results were classified as "very good". The existence of a relationship marketing approach carried out by Bank BPR Sumsel, which emphasized high customer service and high contact with customers, has created good long-term relations between BPR officers and depositors. Although as physically, there were many deficiencies in BPR Sumsel Bank, such as physically outdated office space, lack of support for information technology facilities as in commercial banks, apparently it did not really affect customer perceptions on other intangible quality dimensions, such as reliability, empathy, assurance, and responsiveness of Bank BPR Sumsel officers in serving customers.

Based on the simultaneous statistical testing ( $F$ test) results, it could be seen that overall, the independent variables (Relationship Marketing and Service Quality) had a simultaneous effect on Customer Loyalty at PT Bank Perkreditan Rakyat Sumatera Selatan.

From the results' analysis and discussion, it could be concluded that the better the relationship marketing and service quality implementation, the Bank BPR Sumsel customer loyalty would also increase.

\section{Suggestion}

For the management of PT BPR Sumatera Selatan:

1) Bank BPR Sumsel is expected to develop digital-based information technology, such as websites, EDC machines, Virtual Accounts, Cardless ATMs, and others, so that customers can make transactions faster, easier, and safer.

2) Bank BPR Sumsel must renovate office space, especially the banking hall, to make it more attractive, clean, and comfortable. Besides, Bank BPR Sumsel must anticipate the problem of limited parking access by disseminating the parking bags that have been provided and ensuring parking attendants are ready to assist customers during office operating hours.

3) Bank BPR Sumsel must review customer loyalty program policies, such as giving gifts on birthdays or religious holidays, so that all customers can experience proportional personal treatment and do not experience discriminatory treatment.

4) Bank BPR Sumsel must provide a suggestion box or conduct customer surveys regularly to know customer perceptions and improve marketing strategies and service quality on an ongoing basis. 


\section{Marzuki, Wahab, Widiyanti, \& Sihab}

The Effect of Relationship Marketing and Service Quality on Customer Loyalty ...

\section{For further researchers:}

It is hoped that this research can be used as reference material or further research literature related to relationship marketing and service quality to customer loyalty and information or study material in the field of Marketing Management. The authors realize several deficiencies in this study, including the lack of other variables affecting customer loyalty, such as price, brand image, and customer value.

\section{References}

Armstrong, G., \& Kotler, P. (2015). Marketing an Introduction (12th ed.; S. Wall, ed.). London: Pearson Education Limited.

Ballantyne, D., Christopher, M. \& Payne, A. (2003). Relationship Marketing: Looking Back, Looking Forward. Marketing Theory 3(1), 159-166. Retrieved from https://www.researchgate.net/deref/http $\% 3 \mathrm{~A} \% 2 \mathrm{~F} \% 2 \mathrm{Fdx}$.doi.org $\% 2 \mathrm{~F} 10.1177 \% 2 \mathrm{~F} 14$ 70593103003001009

Basalamah, M.R., Moeljadi, Sunaryo, \& Sudjatno. (2018). The Effect of Service Quality And Relationship Marketing Towards Customer Loyalty for Sharia Banking (Sharia Banking Study in Makassar Indonesia). International Review of Management and Marketing, 8(1), 107-114. https:/ / econjournals.com/index.php/irmm/article/view/5843

Basyir, \& Ramiasih, F. (2017). Pengaruh Implementasi Relationship Marketing Terhadap Customer Loyality (Studi Kasus Pada PD BPR Ciwaringin Kabupaten Cirebon). Jumal Manajemen dan Akuntansi, 12(2), 120-130. https://doi.org/10.32534/jv.v12i2.481

Boateng, S. L. (2019). Online relationship marketing and customer loyalty: a signaling theory perspective. International Journal of Bank Marketing, 37(1), 226-240. https://doi.org/10.1108/IJBM-01-2018-0009

Boonlertvanich, K. (2019). Service quality, satisfaction, trust, and loyalty: the moderating role of main-bank and wealth status. International Journal of Bank Marketing, 37(1), 278-302. https://doi.org/10.1108/IJBM-02-2018-0021

Griffin, J., \& Herres, R. T. (2002). Customer loyalty: How to earn it, how to keep it (p. 18). San Francisco, CA: Jossey-Bass.

Hasan, M. (2019). Relationship Marketing and Customer Loyalty: Experience from Banking Industry of Bangladesh. Journal of Organisational Studies and Innovation, 6(1), 18-32. Retrieved from http://journal.mbacademy.org.uk/relationship-marketing-andcustomer-loyalty-experience-from-banking-industry-of-bangladesh/

Khotimah, C., Suharyono, \& Hidayat, K. (2016). Pengaruh Relationship Marketing dan Brand Image Terhadap Kepuasan dan Loyalitas Pelanggan (Survei terhadap Pelanggan Indihome PT. Telkom, Tbk. STO Klojen Malang). Jurnal Administrasi Bisnis, 36(1), 121-128. Retrieved from http://administrasibisnis.studentjournal.ub.ac.id/index.php/jab/article/view/1402

Kotler, P., \& Keller, K. (2012). Marketing management 14th edition. Prentice-Hall.

Ndubisi, N. O. (2007). Relationship marketing and customer loyalty. Marketing Intelligence \& Planning 25(1), 1-15. https:// doi.org/10.1108/02634500710722425

Nick, M., \& Koenig, K. (2004). Increasing Revenue, Profit, \& Customer Loyalty Through the 360 Sales Cycle. USA: Dearborn Trade Publishing.

Parasuraman, A., Zeithaml, V.A., \& Berry, L.L. (1988). Servqual: A multiple-item scale for measuring consumer perc. Journal of retailing, 64(1), 12-27. 


\section{Marzuki, Wahab, Widiyanti, \& Sihab}

The Effect of Relationship Marketing and Service Quality on Customer Loyalty ...

Ratnasari, D., \& Gumanti, T. A. (2019). Relationship Marketing, Service Quality, Satisfaction, and Customers Loyalty of Bank Sharia Mandiri Banyuwangi. International Journal Of Scientific \& Technology Research, 8(06), 7-10. Retrieved from http://www.ijstr.org/finalprint/june2019/Relationship-Marketing-Service-Quality-Satisfaction-And-CustomersLoyalty-Of-Bank-Sharia-Mandiri-Banyuwangi.pdf

Salilo, F. A. (2019). Analisis Pengaruh Kepercayaan dan Kualitas Produk terhadap Loyalitas Nasabah dengan Kepuasan Nasabah sebagai Media Intervening. Jurnal Riset Bisnis dan Manajemen, 7(1), 413-432.

Saputra, E., Zulkarnain, \& Samsir. (2018). Pengaruh Kualitas Jasa dan Kepuasan Nasabah Terhadap Kepercayaan dan Loyalitas Nasabah KUR MIKRO Bank BRI Kota Dumai. Jurnal Ekonomi, 26(2), 1-17. Retrieved from http://download.garuda.ristekdikti.go.id/article.php?article=1709189\&val=2268\&title $=$ PENGARUH $\% 20$ KUALITAS $\% 20 J A S A \% 20$ DAN $\% 20$ KEPUASAN $\% 20$ NASABA H\%20TERHADAP\%20KEPERCAYAAN\%20DAN\%20LOYALITAS\%20NASAB AH $\% 20$ KUR $\% 20$ MIKRO $\% 20$ BANK $\% 20$ BRI $\% 20$ KOTA $\% 20$ DUMAI

Solangi, B., Talpur, U., Shaikh, S.S., Mushatque, T., \& Channa, M. A. (2019). Relationship Marketing as an Orientation to Customer Retention : Evidence from Banks of Pakistan. Journals International Business Research 12(7), 133-140. https://doi.org/10.5539/ibr.v12n7p133

Stauss, B. (2013). Using New Media for Customer Interaction: A Challenge for Relationship Marketing. Relationship Marketing. https://doi.org/10.1007/978-3-662-09745-8 13

Sugiyono, P. D. (2017). Metode Penelitian Kuantitatif, Kualitatif, dan R\& D. Bandung: Alfabeta.

Synathra, V., \& Sunarti. (2018). Pengaruh Relationship Marketing Terhadap Kepuasan Nasabah dan Dampaknya Pada Loyalitas Nasabah (Survei pada Nasabah Tabungan BCA Kantor Kas Sawojajar Kota Malang). Jurnal Administrasi Bisnis (JAB), 55(1), 115124. Retrieved from http://administrasibisnis.studentjournal.ub.ac.id/index.php/jab/article/view/2248

Tjiptono, F. \& Dewi, P. S. (2013). Memahami komplain konsumen dan respon perusahaan di surat kabar nasional. Prosiding Seminar Nasional \& Call for Paper Forum Manajemen Indonesia (FMI) ke-5, Fakultas Ekonomi Universitas Tanjung Pura, Pontianak, 23-24.

Tjiptono, F. (2010). Manajemen Jasa. Yogyakarta: Andi Offset.

Tjiptono, F. (2019). Pemasaran Jasa - Prinsip, Penerapan, dan Penelitian, Edisi 1. Yogyakarta; Andi Offset.

Zeithaml, V. A., Bitner, M. J., \& Gremler, D. D. (2013). Services marketing: Integrating customer focus across the firm. 6th Ed. Boston, Mass: Mc.Graw-Hill

Zichermann, G., \& Linder, J. (2010). Game_Based Marketing; Inspire Customer Loyalty Through Rewards, Challenges, and Contests. New Jersey: John Wiley \& Son, Inc. 